\title{
Scientific production of the Brazilian National Council for Scientific and Technological Development (CNPq) researchers in the fields of tropical medicine and infectious diseases
}

\author{
Gabriela Pereira Dias ${ }^{[1]}$, Daniella Reis Barbosa Martelli[1],[2], Lucimar Batista de Almeida ${ }^{[3]}$, \\ Gabriel Albuquerque Barbosa ${ }^{[2]}$, Eduardo Araújo Oliveira ${ }^{[4]}$ \\ and Hercílio Martelli Júnior ${ }^{[1],[2]}$
}

[1]. Programa de Pós-Graduação em Ciências da Saúde, Universidade Estadual de Montes Claros, Montes Claros, MG, Brasil.

[2]. Departamento de Odontologia, Universidade Estadual de Montes Claros, Montes Claros, MG, Brasil.

[3]. Conselho Nacional de Desenvolvimento Científico e Tecnológico (CNPq), Brasília, DF, Brasil.

[4]. Departamento de Pediatria, Universidade Federal de Minas Gerais, Belo Horizonte, MG, Brasil.

\section{Dear Editor in Chief:}

Brazil has two main science funding agencies: the Coordination for the Improvement of Higher Education Personnel (CAPES), which provides financial support and evaluates student performance in postgraduate courses, and the National Council for Scientific and Technological Development $(\mathrm{CNPq})$, which is devoted primarily to research funding. $\mathrm{CNPq}$ also offers a particular form of research grant called scientific productivity fellowship. Researchers who are the recipients of this grant are currently classified into two main categories: researcher category 1 and researcher category 2; category 1 researchers are subdivided into four levels: $1 \mathrm{~A}, 1 \mathrm{~B}, 1 \mathrm{C}$, and $1 \mathrm{D}^{1}$.

According to the CNPq Advisory Committee, the criteria for the selection and classification of candidates for the scientific productivity scholarship include scientific output, human resource training, contribution to innovation, coordination and participation in research projects, participation in editorial activities, and scientific management. The CNPq Advisory

Corresponding author: Gabriela Pereira Dias.

e-mail: gabi_pereiradias@hotmail.com

Orcid: 0000-0003-3143-0284

Received 18 February 2019

Accepted 29 April 2019
Committee also stated that, because of the limited supply of scholarships, the following criteria are also used as classification parameters for all categories/levels: (1) number of publications and impact factor of the respective journals; (2) number of national and foreign patents; (3) number of $\mathrm{PhD}$ theses oriented and approved; (4) number of Master's dissertations oriented and approved; (5) leadership of research groups; and (6) h-index (http://www.cnpq.br/web/guest/view/2).

Despite facing a crisis in scientific investments ${ }^{3}$, Brazil stands out worldwide in key research areas, such as tropical medicine, dentistry, parasitology, and, more recently, the Zika virus and microcephaly ${ }^{4}$. In this context, many studies have examined the profile and scientific production of researchers supported by CNPq in several fields of knowledge ${ }^{5-9}$.

This letter describes the profile and scientific production of recipients of CNPq scientific productivity scholarships in tropical medicine and infectious diseases. We initially established a database of 542 researchers registered as $\mathrm{CNPq}$ medical fellows based on a list provided by the research funding itself in March 2018 (http://www.cnpq.br/web/guest/bolsistasvigentes). Of the 542 medical researchers, the main areas of investigation of 51 researchers were tropical medicine and infectious diseases.

Using the Lattes curriculum directory publicly available on the Lattes Platform (http://buscatextual.cnpq.br/buscatextual/ busca.do?metodo=apresentar), we constructed a database with information on each researcher comprising institution, time 
TABLE 1: Profile of the researchers in tropical medicine and infectious diseases granted with a scientific productivity fellowship by the Brazilian National Council for Scientific and Technological Development (CNPq).

\begin{tabular}{|c|c|c|c|c|c|c|c|c|c|c|c|}
\hline \multirow[t]{2}{*}{$\begin{array}{l}\text { Number of } \\
\text { researchers }\end{array}$} & \multicolumn{5}{|c|}{ Grant level (n) } & \multicolumn{2}{|c|}{ Published articles (n) } & \multicolumn{4}{|c|}{ Training of human resources $(n)$} \\
\hline & & & & & & & & & SIS & MSc & PhD \\
\hline \multirow{2}{*}{51} & 4 & 7 & 6 & 12 & 22 & Median & 138.98 & Median & 19.68 & 21.66 & 10.70 \\
\hline & & & & & & Median & 44.37 & Median & 4.78 & 6.21 & 3.82 \\
\hline
\end{tabular}

SIS: Scientific Initiation Student; MSc: Master of Science; PhD: Doctor of Philosophy.

elapsed since earning the $\mathrm{PhD}$ degree, scientific production (published papers), and human resource training (supervision of undergraduate, Master's, and PhD students).

For the analysis of scientific production, we considered all publications and advising of the researchers within the period between their first published scientific paper and December 2017. We also analyzed the publications and advising from 2013 to 2017 (average duration of scholarship).

The 51 researchers belonged to 14 Brazilian states: São Paulo ( $\mathrm{n}=17 ; 33.33 \%)$, Rio de Janeiro $(\mathrm{n}=11 ; 21.57 \%)$, Minas Gerais ( $\mathrm{n}=6 ; 11.77 \%)$, Bahia $(\mathrm{n}=4 ; 7.85 \%)$, Rio Grande do Sul $(n=3 ; 5.88 \%)$, Ceará $(n=2 ; 3.92 \%)$, Amazonas $(n=1$; $1.96 \%)$, Goiás ( $\mathrm{n}=1 ; 1.96 \%)$, Mato Grosso $(\mathrm{n}=1 ; 1.96 \%)$, Mato Grosso do Sul ( $\mathrm{n}=1 ; 1.96 \%)$, Paraná $(\mathrm{n}=1 ; 1.96 \%)$, Pernambuco $(\mathrm{n}=1 ; 1.96 \%)$, Piaú $(\mathrm{n}=1 ; 1.96 \%)$, and Santa Catarina $(\mathrm{n}=1$; $1.96 \%)$; most of them were men $(\mathrm{n}=32 ; 62.75 \%)$. Regarding home institution, tropical medicine and infectious diseases researchers were distributed among 19 different institutions in the country. The median time elapsed since earning the $\mathrm{PhD}$ degree was 19.10 years (IQ, 6-41).

Throughout their academic career, the 51 researchers had published 7,088 articles in scientific journals, with an average of 138.98 articles per researcher (ranging from 41 to 351 articles). Of the 7,088 articles, 4,965 (70.04\%) were indexed in the Web of Science database (an average of 97.35 articles per researcher) and 5,276 (74.43\%) articles were indexed in the Scopus database (an average of 103.45 articles per researcher). They also advised 1,004 undergraduate students conducting research (median of 19.68; range: 0-86), 1,105 Master's students (median of 21.66; range: 5-63), and $546 \mathrm{PhD}$ students (median of 10.70; range: $1-36)$. The median h-index at ISI of the fellows was 18.82 (Table 1). Most of the CNPq researchers in the areas of tropical medicine and infectious diseases were men and were concentrated in the Southeast region of Brazil.

A clear limitation of this study was that it considered only the recipients of $\mathrm{CNPq}$ productivity scholarships in the area of Medicine in the analysis. It should be noted that many researchers with their scientific production considerably related to tropical medicine and infectious diseases are associated with other CNPq committees, such as Immunology, Biophysics, Genetics, Microbiology, and Parasitology.

In sum, our findings show that the tropical medicine and infectious diseases fellows who are recipients of the CNPq productivity scholarship present a remarkable scientific production, as also observed in other areas, such as medicine, pharmacy, and dentistry ${ }^{8-11}$. The most significant scientific publications are indexed in the Scopus (74.43\%) and Web of Science (70.04\%) databases. However, the comparison between these researchers and similar groups from other countries is difficult because of the scarcity of studies in this field. Studies addressing this issue could effectively contribute to a more resourceful distribution of resources among competing researchers.

\section{ACKNOWLEDGMENT}

We thank the Minas Gerais State Research Foundation FAPEMIG, Minas Gerais, Brazil, and the National Council for Scientific and Technological Development - CNPq, Brazil.

\section{REFERENCES}

1. Arruda D, Bezerra F, Neris VA, Toro PR, Wainer J. Brazilian computer science research: Gender and regional distributions. Scientometrics. 2009;79(6):651-65.

2. Brazilian Council for Scientific and Technological Development (CNPq). Portal CNPq. (http://www.cnpq.br/web/guest/view/). 2019.

3. Barbuy B. Crisis in Brazil. Science. 2018; 361(6409)1293.

4. Coordination for the Improvement of Higher Education Personnel (CAPES). Proposta de Aprimoramento do Modelo de Avaliação da PG. Documento Final da Comissão Nacional de Acompanhamento do PNPG 2011-2020 - 10/10/2018. (http://www.capes.gov.br/pt/).

5. Barata RB, Goldbaum M. [A profile of researchers in public health with productivity grants from the Brazilian National Research Council (CNPq)]. Cad Saude Publica. 2003;19(6):1863-76.

6. Mendes PHC, Martelli DR, Souza WP, Filho SQ, Martelli Junior H. Perfil dos pesquisadores bolsistas de produtividade científica na medicina no CNPq, Brasil. Rev Bras Educ Med. 2010; 34(4):535-41.

7. Santos NCF, Candido LFO, Kuppens CL. Produtividade em pesquisa do CNPq: análise do perfil dos pesquisadores da química. Quimica Nova. 2010;33(2):489-95. 
8. Oliveira EA, Colosimo EA, Martelli DR, Quirino IG, Oliveira MC, Silva LS, et al. Comparison of Brazilian researchers in clinical medicine: are criteria for ranking well-adjusted?. Scientometrics. 2012;90(2): 429-43.

9. de Andrade RS, Martelli DRB, Almeida OP, Lopes MA, Swerts MSO, Pires FR, et al. Brazilian scientific production in Oral Medicine and Oral Pathology. Oral Surg Oral Med Oral Pathol Oral Radiol. 2018;125(2):170-81.

10. Oliveira EA, Peicots-Filho R, Martelli DR, Quirino IG, Oliveira MCL,
Duarte $\mathrm{MG}$, et al. Is there a correlation between journal impact factor and researchers' performance? A study comprising the fields of clinical nephrology and neurosciences. Scientometrics. 2013;97(3):149-60.

11. Rodrigues LO, Gouvea MM, Marques FCC, Mourao SC. Overview of the scientific production in the Pharmacy area in Brazil: profile and productivity of researchers granted with fellowships by the National Council for Scientific and Technological Development. Scientometrics. 2017;110(3):1157-71. 